\title{
Assessing the completeness of perioperative anesthetic record documentation in a tertiary hospital
}

\author{
Hayatul Akma Bolhan, MB, BCh, BAO ${ }^{1} \bowtie$, Nurlia Yahya, MBBS $^{2} \varangle$, Azarinah Izaham ${ }^{3} \bowtie$, \\ Wan Rahiza Wan Mat ${ }^{3} \bowtie$, Raha Abdul Rahman ${ }^{3} \bowtie$, Qurratu Aini Musthafa ${ }^{3} \bowtie$
}

Authors' affiliations:

1- Anesthetic registrar, Department of Anesthesiology \& Intensive Care, Faculty of Medicine, Universiti Kebangsaan Malaysia, Jalan Yaacob Latif, Bandar Tun Razak-56000, Cheras, Kuala Lumpur, Malaysia..

2- Senior Lecturer, Department of Anesthesiology \& Intensive Care, Faculty of Medicine, Universiti Kebangsaan Malaysia, Jalan Yaacob Latif, Bandar Tun Razak-56000, Cheras, Kuala Lumpur, Malaysia.

3- Department of Anesthesiology \& Intensive Care, Faculty of Medicine, Universiti Kebangsaan Malaysia, Jalan Yaacob Latif, Bandar Tun Razak-56000, Cheras, Kuala Lumpur, Malaysia.

Correspondence: Azarinah Izaham, E-mail: azaizaham@yahoo.com; Phone: 122216141

\section{Abstract}

Background and Objective: Many previous studies assessing the completeness of perioperative documentation of surgical patients were reported to be inadequate and unsatisfactory. The aim of this study was to compare the perioperative anesthetic record (PAR) at our tertiary care institution to a standard guideline and have an audit of its completeness.

Methodology: It was a prospective, observational study, done in the general operating theater of Universiti Kebangsaan Malaysia Medical Centre (UKMMC). We compared our PAR to the American Society of Anesthesiologists (ASA) policy statement on documentation of anesthesia care. We audited the completeness of PAR documentation of 358 patients by using a self-generated checklist which was created in accordance to the PAR parameters. A total of 44 parameters were studied covering three phases; preoperative, peroperative and post-operative phases.

Results: Although the UKMMC PAR varied from the ASA guidelines, various salient parameters were identical in both. None of the perioperative forms were completely filled throughout the three perioperative phases. Out of 44 parameters studied, only 2 parameters were completely filled, which were medications administered and fluid therapy.

Conclusion: Parameters given in the UKMMC PAR varied with the ASA guidelines and the documentation was found to be only partially complete. Hence, necessary modification of the current PAR in our institution, and the stress on filling it completely is needed to improve the quality of perioperative anesthetic documentation.

Keywords: Audit; Completeness; Perioperative; Anesthetic record; Documentation

Citation: Bolhan HA, Yahya N, Izaham A, Mat WRW, Rahman RA, Musthafa QA. Anaesth. pain intensive care 2020;24(6):635-644 Received: 23 April 2020, Reviewed: 17 August 2020, Revised: 18 October 2020, Accepted: 27 October 2020

\section{Introduction}

The anesthetic record is a tool which facilitates the anesthesiologist's documentation of all surgical patients that require anesthetic care and should have accurate and concise information regarding patient's relevant preoperative evaluation, intraoperative procedures and data, as well as postoperative orders. It also fulfills other roles; being a fundamental interdisciplinary communication tool, a source of information for research and quality assurance projects and a legal document that can be used in any medicolegal proceedings. ${ }^{1-2}$

It is a basic responsibility of anesthesiologists to ensure that their anesthetic documentation is complete and accurate. Even if they may be busy monitoring critically ill patients during surgery, they still need to document all important information on the anesthetic record form. Inadequate perioperative documentation can affect the quality of patient care which can lead to potential future anesthetic calamities to these patients which may subsequently have medico-legal 
Table 1-A: Comparison between the ASA recommendation on documentation of anesthesia care and the parameters present on UKMMC's PAR in the preoperative phase.

\begin{tabular}{|c|c|}
\hline \multicolumn{2}{|c|}{ PREOPERATIVE PHASE } \\
\hline \multirow[t]{2}{*}{ ASA recommendations } & UKMMC PAR \\
\hline & Date of preoperative assessment \\
\hline \multirow[t]{2}{*}{ Patient identification } & Patient's name, RN, age, gender \\
\hline & Diagnosis \\
\hline \multirow[t]{6}{*}{ Procedure identification } & Surgical procedure \\
\hline & Name of anaesthetist \\
\hline & Name of surgeon \\
\hline & Type of operation \\
\hline & Anaesthesia given in: \\
\hline & Consent given in: \\
\hline \multicolumn{2}{|l|}{ Anticipated disposition } \\
\hline Medical history & Medical history \\
\hline Surgical history & Surgical history \\
\hline Anesthetic history & Anesthetic history \\
\hline Current medications list & Current medication \\
\hline Allergies/adverse drug reaction & Allergies \\
\hline \multicolumn{2}{|l|}{ NPO status } \\
\hline \multicolumn{2}{|l|}{$\begin{array}{l}\text { Documenting the presence of and the } \\
\text { perioperative plan for existing advance } \\
\text { directives }\end{array}$} \\
\hline Appropriate physical examination & General clinical findings \\
\hline Vital signs & $\begin{array}{l}\text { Heart rate } \\
\text { blood pressure }\end{array}$ \\
\hline Weight and height & Weight and Height \\
\hline Airway assessment & $\begin{array}{l}\text { Airway and trachea } \\
\text { Teeth, Denture }\end{array}$ \\
\hline Cardiopulmonary examination & $\begin{array}{l}\text { Lungs } \\
\text { Heart sound and rhythm } \\
\text { Peripheral pulses }\end{array}$ \\
\hline $\begin{array}{l}\text { Objective diagnostic data review (eg; } \\
\text { Laboratory, ECG, X-ray) }\end{array}$ & $\begin{array}{l}\text { Laboratory investigations (ECG, CXR, } \\
\text { Other investigations }\end{array}$ \\
\hline \multicolumn{2}{|l|}{ Medical consultation (when applicable) } \\
\hline \multicolumn{2}{|l|}{ ASA status } \\
\hline \multirow[t]{2}{*}{ Anaesthetic plan } & Special orders \\
\hline & Blood orders \\
\hline \multicolumn{2}{|l|}{ Informed consent documentation } \\
\hline $\begin{array}{l}\text { Premedication/prophylactic antibiotic } \\
\text { administration (if indicated) }\end{array}$ & Premedication \\
\hline
\end{tabular}

implications..$^{3-5}$ Some of the examples of poor perioperative documentations include failure to document the occurrence of allergic reactions or unanticipated difficult airway intraoperatively. ${ }^{6}$

Although our local professional anesthesia body has come up with recommendations on preanesthetic assessment, it has yet to give guidelines on the perioperative anesthetic documentation. $^{7}$ Thus, the adequacy or completeness of perioperative documentation in Malaysia has not been assessed or reviewed. Therefore, this study was done to compare our tertiary institution's perioperative anesthetic records (PAR) with the policy statement on documentation of anesthesia care by the American Society of Anesthesiologists (ASA) and to assess the completeness of UKMMC PAR documentation throughout the peri-operative period. ${ }^{8}$

\section{Methodology}

This prospective observational study was conducted in our general operating theatre (GOT), from 1st to 30th September 2018, after approval by both the Dissertation Committee of the Department of Anesthesiology \& Intensive Care and Medical Research \& Ethics Committee of UKMMC (Project code: FF-2018-315). PAR which were complete in all three phases (preoperative, intraoperative and postoperative) of anesthetic documentation for surgical procedures during the study period were included. PAR of surgical procedures that were postponed or cancelled on the day of surgery in the GOT, and those of patients who 
Table 1-B: Comparison between the ASA recommendation on documentation of anesthesia care and the parameters present on UKMMC's PAR in the intraoperative and postoperative phases

\begin{tabular}{|c|c|}
\hline \multicolumn{2}{|c|}{ INTRAOPERATIVE PHASE } \\
\hline ASA recommendations & UKMMC PAR \\
\hline \multicolumn{2}{|l|}{ Patient re-evaluation } \\
\hline \multicolumn{2}{|l|}{$\begin{array}{l}\text { Confirmation of } \\
\text { equipment/medications/staffs }\end{array}$} \\
\hline Physiologic monitoring data & Vital signs \\
\hline \multirow[t]{3}{*}{ Medications administered } & Medications administered \\
\hline & Induction time \\
\hline & Reversal time \\
\hline Techniques & $\begin{array}{l}\text { Intubations } \\
\text { Inhalational agents } \\
\text { Ventilation } \\
\text { Regional block }\end{array}$ \\
\hline \multirow[t]{3}{*}{ Position } & Position \\
\hline & Tourniquet time \\
\hline & Pharyngeal airway apparatus \\
\hline \multirow[t]{3}{*}{ Intravenous fluids } & Fluid therapy \\
\hline & Blood loss \\
\hline & Blood products given \\
\hline \multicolumn{2}{|l|}{$\begin{array}{l}\text { Additional procedures performed (Eg: } \\
\text { catheterization) }\end{array}$} \\
\hline \multicolumn{2}{|l|}{$\begin{array}{l}\text { Unusual or noteworthy events during } \\
\text { surgery and anaesthesia care }\end{array}$} \\
\hline \multicolumn{2}{|l|}{ Patient status at transfer of care } \\
\hline \multicolumn{2}{|l|}{$\begin{array}{l}\text { Criteria demonstrating patient status } \\
\text { at transfer of care }\end{array}$} \\
\hline \multicolumn{2}{|c|}{ POSTOPERATIVE PHASE } \\
\hline ASA Recommendatioon & UKMMC PAR \\
\hline $\begin{array}{l}\text { Significant or unexpected post- } \\
\text { procedural events/complications }\end{array}$ & Post-operative orders/complications \\
\hline \multirow[t]{3}{*}{$\begin{array}{l}\text { Postanaesthesia evaluation } \\
\text { documenting physiologic condition } \\
\text { and presence/absence of } \\
\text { anaesthesia related complications or } \\
\text { complaints }\end{array}$} & \\
\hline & Discharge time \\
\hline & Anesthetist's signature and name \\
\hline
\end{tabular}

patients were transferred out to the ward from the recovery bay. The completeness of the PAR studied were evaluated by using a checklist, which was generated by the researcher based on the anesthetic record used in UKMMC. The checklist contained three phases (see Appendix A, B and C respectively) with a total of 44 parameters. The checklist completeness was quantified as 'complete', 'incomplete' or 'no' based on predefined measures and parameters. ${ }^{4}$ Parameters that were documented correctly on the forms would be considered as 'complete', parameters that were documented partially would be considered as 'incomplete' and finally any parameters that were left blank on the form would be considered as 'no' (no documentation at all).

The sample size was calculated using Epi Info ${ }^{\mathrm{TM}} 7$, where population size for GOT patients over one month was approximately 500 . Based on the previous study done by Elhalawani et al. ${ }^{3}$ the percentage of overall record completeness in his study was $32 \%$. Therefore, with an $80 \%$ power of the study, 95\% confidence level and anticipated $10 \%$ drop-out rate, an estimated 358 PAR were required for this study. underwent repetitive surgical procedures within the study duration were excluded.

The primary researcher reviewed the PAR daily in GOT once the postoperative orders were completed by the anesthetic trainees or anesthetists, before the
Statistical analysis: The data were analyzed using Statistical Package for Social Science (SPSS) version 23.0. The descriptive analyses included the observed frequencies calculation with the respective percentages for each categorical variable. 


\section{Results}

A total of 358 PAR were included in this audit. However, only 354 PAR were analyzed, as 4 PAR were found to have illegible handwriting. Based on Table 1, the parameters present on UKMMC's PAR differ from the ASA recommendations, as some
Further analysis was done for the completeness of the studied PAR in totality. None of the PAR scored 'complete' in all the three phases. In the intraoperative phase, only two parameters achieved complete documentation which were 'medications administered' and 'fluid therapy', as shown in Table 2. However, none of the parameters in the preoperative

Table 2-A: The percentage of completeness of each parameter present in the UKMMC PAR. The percentage of completeness of sub-parameters under the 'Airway and respiratory' and 'Cardiovascular' sections were also included.

\begin{tabular}{|c|c|c|c|}
\hline PREOPERATIVE & Yes - Complete & Yes - Incomplete & No \\
\hline & n (\%) & n (\%) & n (\%) \\
\hline Date of preop assessment & 351 (99.2) & $0(0.0)$ & $3(0.8)$ \\
\hline Patient's name & 350 (98.9) & $0(0.0)$ & $4(1.1)$ \\
\hline Patient's RN & 350 (98.9) & $0(0.0)$ & $4(1.1)$ \\
\hline Patient's age & 350 (98.9) & $0(0.0)$ & $4(1.1)$ \\
\hline Patient's gender & 350 (98.9) & $0(0.0)$ & $4(1.1)$ \\
\hline Name of surgeon & $4(1.1)$ & $0(0.0)$ & $350(98.9)$ \\
\hline Type of operation & 339 (95.8) & $0(0.0)$ & $15(4.2)$ \\
\hline Anaesthesia given in: & $200(56.5)$ & $0(0.0)$ & $154(43.5)$ \\
\hline Consent given in & $164(46.3)$ & $0(0.0)$ & $190(53.7)$ \\
\hline Past medical history & $346(97.7)$ & $2(0.6)$ & $6(1.7)$ \\
\hline Previous surgery & $220(62.1)$ & $54(15.3)$ & $80(22.6)$ \\
\hline Anaesthetic history & 237 (66.9) & $25(7.1)$ & $92(26.0)$ \\
\hline Current medications & $244(68.9)$ & $34(9.6)$ & $76(21.5)$ \\
\hline Allergies & 290 (81.9) & $18(5.1)$ & $46(13.0)$ \\
\hline General clinical findings & $272(76.8)$ & $82(23.2)$ & $0(0.0)$ \\
\hline Patient's weight & $257(72.6)$ & $0(0.0)$ & 97 (27.4) \\
\hline Airway and respiratory & $105(29.7)$ & 237 (66.9) & $12(3.4)$ \\
\hline $\begin{array}{ll}\text { - } & \text { Teeth } \\
\text { - } & \text { Denture } \\
\text { - } & \text { Airway and trachea } \\
\text { - } & \text { Lungs }\end{array}$ & $\begin{array}{l}108(30.5) \\
105(29.7) \\
289(81.6) \\
342(96.6)\end{array}$ & & $\begin{array}{c}246(69.5) \\
249(70.3) \\
65(18.4) \\
12(3.4)\end{array}$ \\
\hline Cardiovascular & $114(32.2)$ & $222(62.7)$ & $18(5.1)$ \\
\hline $\begin{array}{ll}\text { - } & \text { Heart rate } \\
\text { - } & \text { Blood pressure } \\
\text { - } & \text { Peripheral pulse } \\
\text { - } & \text { Sound and rhythm } \\
\end{array}$ & $\begin{array}{l}336(94.9) \\
310(87.6) \\
135(38.1) \\
114(32.2) \\
\end{array}$ & & $\begin{array}{c}18(5.1) \\
44(12.4) \\
219(61.9) \\
240(67.8)\end{array}$ \\
\hline Other system findings & $92(26.0)$ & $42(11.9)$ & $220(62.1)$ \\
\hline Laboratory investigations & $182(51.4)$ & 118 (33.3) & 54 (15.3) \\
\hline Other investigations & 120 (33.9) & $66(18.6)$ & $168(47.5)$ \\
\hline Special orders & 348 (98.3) & $0(0.0)$ & $6(1.7)$ \\
\hline Blood orders & $221(62.4)$ & $0(0.0)$ & $133(37.6)$ \\
\hline Premedication prescribed & $54(15.3)$ & $0(0.0)$ & $300(84.6)$ \\
\hline
\end{tabular}

parameters in the under study PAR were not included by ASA, and vice versa. and postoperative phase achieved complete documentation. Nonetheless, there were parameters 
that had a high percentage of completeness (> 95\%). Regarding 'airway and respiratory' and 'cardiovascular' parameters, sub-parameters such as 'heart rate', 'blood pressure' and 'lung' were seen to be relatively well documented compared to the other sub-parameters in those sections.

Table 2-B: The percentage of completeness of each parameter present in the UKMMC PAR. The percentage of completeness of sub-parameters under the 'Airway and respiratory' and 'Cardiovascular' sections were also included.

\begin{tabular}{l|c|c|c}
\multicolumn{1}{c|}{$\begin{array}{c}\text { INTRAOPERATIVE AND } \\
\text { POSTOPERATIVE }\end{array}$} & Yes -Complete & Yes - Incomplete & No \\
\hline Medications administered & $\mathrm{n}(\%)$ & $\mathrm{n}(\%)$ & $0(0.0)$ \\
\hline Induction time & $354(100)$ & $0(0.0)$ & $8(2.3)$ \\
\hline Reversal time & $127(35.9)$ & $219(61.9)$ & $171(48.3)$ \\
\hline Regional block & $8(2.3)$ & $175(49.4)$ & $189(53.2)$ \\
\hline Tourniquet time & $165(46.8)$ & $0(0.0)$ & $272(76.8)$ \\
\hline Position of patient & $70(19.8)$ & $12(3.4)$ & $29(8.2)$ \\
\hline Pharyngeal airway apparatus & $325(91.8)$ & $0(0.0)$ & $312(88.1)$ \\
\hline Intubations & $42(11.9)$ & $0(0.0)$ & $0(0.0)$ \\
\hline Inhalational agents & $344(97.2)$ & $10(2.8)$ & $2(0.6)$ \\
\hline Ventilation & $334(94.4)$ & $18(5.1)$ & $3(0.8)$ \\
\hline Vital signs & $261(73.7)$ & $90(25.4)$ & $0(0.0)$ \\
\hline Blood loss & $332(93.8)$ & $22(6.2)$ & $154(43.5)$ \\
\hline Fluid therapy & $200(56.5)$ & $0(0.0)$ & $0(0.0)$ \\
\hline Blood products given & $354(100)$ & $0(0.0)$ & $8(2.3)$ \\
\hline Postoperative orders & $10(2.8)$ & $336(94.9)$ & $38(8.5)$ \\
\hline Discharge time & $324(91.5)$ & $0(0.0)$ & $38(10.7)$ \\
\hline Anesthetist's signature and name & $316(89.3)$ & $13(3.7)$ & \\
\hline
\end{tabular}

\section{Discussion}

While other professional bodies such as the ASA and the Australian and New Zealand College of Anesthetists (ANZCA) have come up with statements on documentation of anesthesia care, our local professional body - the Malaysian Society of Anaesthesiologists (MSA) has yet to come out with a standard format or guideline for the PAR to be used in our country. Consequently, our public sector hospitals use a standardized PAR, but different teaching institutions and private sector hospitals have had their own designs and formats of PAR. Nevertheless, all the professional anesthesia bodies worldwide strongly emphasize that PAR documentation must be adequate and complete as it is important for patient safety, quality assurance and medico-legal purposes..$^{7-16}$

We chose the 'ASA Statement on Documentation of Anesthesia Care' as the standard guideline for comparison with our PAR because its' policy update was more recent as compared to the ANZCA guideline. ${ }^{8,9}$ There was a study done previously in an Australian teaching hospital that compared the adequacy of perioperative anesthetic documentation and its' adherence to the Australian guidelines, and found it to be unsatisfactory. ${ }^{3}$ Similar findings were seen in our study where majority of the studied PAR were partially documented throughout the three phases of anesthesia care.

Marco et al. stated in their study that there were factors that could affect the quality of documentation such as 
the availability of information during the documentation process, provider interest and the ease of use of the forms. ${ }^{5}$ This may be reflected in our study as well. Certain information such as patients' demographics i.e. name, age, gender and registration number were easily obtained from the provided hospital sticker making it more convenient during the documentation process and thus resulting in a high completion rate of documentation as compared to other parameters such as patients' medical histories, clinical examination and investigations which may not be readily available in the patient's case notes.

This study included a variety of elective, emergency and daycare surgeries and anesthesia techniques (general anesthesia, regional anesthesia or a combination of both techniques) with a mixture of adult and pediatric patients. Therefore, there are parameters in the preoperative and intraoperative phases which may not be relevant to all cases and thus may have contributed to the partial documentation in the studied PAR. For example, prescribing pharmacological premedication may not be relevant to emergency and daycare surgeries as well as pediatric patients, while documentation of reversal time in the intraoperative phase is not applicable for cases done under regional anesthesia.

Marco et al. also concluded that a well-designed form can improve the quality of preoperative record keeping. ${ }^{5}$ The layout and structure of the form should be easy to use in order to achieve a high compliance rate of documentation. The PAR used in this study has been used for more than 20 years and has yet to be restructured or modified in any way. Some of the parameters stated in the studied PAR were irrelevant and not in keeping with ASA recommendations, although the salient parameters were actually included in both. Examples of irrelevant parameters were 'anesthesia given in' and 'consent given' in the preoperative part of the form. The completion rates of these parameters were poor as they were deemed to be unnecessary and often missed out by our anesthesia trainees.

The studied PAR also lacked some important parameters as per ASA recommendations, such as ASA physical status and nil per oral (NPO) status. The ASA physical status is commonly used to stratify perioperative outcomes based on the patient's preoperative medical condition, while NPO status helps to identify pulmonary aspiration risk, thus helping to guide in deciding the anesthetic plan and mode of anesthetic technique. Although the PAR in our study did not provide specific sections for these two parameters, it was actually common to encounter these parameters being documented elsewhere on the form. Previous studies also did not have a satisfactory completion rate either for these two parameters. Both Swart et al. and Woldegerima et al. found that only $44.4 \%$ and $71.3 \%$ of their PAR forms were completed for ASA status respectively, while documentation of NPO status was found to be even lower at only $1.2 \%$ and $9 \%$ respectively in their studies. ${ }^{4,6}$

This study was carried out in a teaching hospital which is a place of practice and learning for anesthetic trainees who have come from various anesthetic practice backgrounds all over the country prior to joining this institution for sub-specialty training. The lack of familiarity and experience especially of new trainees on completing the PAR which may be different from the ones used in their previous hospitals may be another factor that contributes to the incomplete documentation seen in this study. This is also seen in the study by Woldegerima et al. which was conducted in a tertiary teaching hospital where they found that most of the pre-anesthetic evaluations were done by junior doctors and thus contributed to poor documentation practice. ${ }^{6}$

To improve documentation practice, we recommend that this institution needs to modify the existing PAR to a more concise and well-designed form that conforms to standards and recommendations set by professional bodies. Introducing and implementing electronic-based documentation system in the hospital should be considered as well to improve the quality of information obtained and documentation practice, as had been shown by previous audits. ${ }^{3}$ However, a limitation to the establishment of digital documentation would include a higher cost for maintenance of equipment required. Apart from that, the importance of good quality PAR documentation should be emphasized to our anesthesia trainees by conducting training and regular audits with active supervision by senior anesthetists to ensure a better quality of anesthetic record keeping.

In this study, the percentage of documentation completeness of our PAR does not truly reflect the actual anesthetic management of our patients and their 
outcomes. A further study to correlate the documentation completeness of PAR with the outcome of anesthetic management is recommended.

\section{Conclusion}

In conclusion, although the salient parameters were similar in both, there were parameters in the UKMMC PAR that differed from the standard ASA guidelines. There were parameters recommended by the ASA guideline that could be added to our PAR to make it complete. Documentation of PAR in UKMMC was found to be partially complete. Both, necessary modification of the current PAR as well as the departmental focus is required to improve the quality of perioperative anesthetic documentation.

\section{Conflict of interest}

None declared by the authors

\section{Authors' contribution}

HAB: Data collection

NY: Concept, supervision

AI: Manuscript preparation, corresponding author

WRWM, RAR: Manuscript preparation

QAM: Data analysis

\section{References}

9. Raymer K. The Anesthetic record: How content and design influence function in anesthetic practice and beyond. J Anesth Clinic Res. 2011;4:282. DOI: 10.4172/2155-6148.1000282

10. Modell JH, Layon J, Modell CS. Miller RD. (ed.) Ethical and Legal Aspects, Anesthesia. 5 $5^{\text {th }}$ ed. Churchill Livingstone, Philadelphia; 2000. p.2721-41.

11. Elhalawani I, Jenkins S, Newman N. Perioperative anesthetic documentation: Adherence to current Australian guidelines. J Anaesthesiol Clin Pharmacol. 2013;29(2):211-215. [PubMed] DOI: 10.4103/09709185.111726

12. Swart W, Kuhn A. An audit of documented preoperative evaluation of surgery patients at Universitas Academic Hospital, Bloemfontein. South Afr J Anaesth Analg. 2015;21(4):107-112. $\underline{10.1080 / 22201181.2015 .1057030}$

13. Marco AP, Buchman D, Lancz C. Influence of form structure on the anesthesia preoperative evaluation. $J$ Clin Anesth. 2003:15(6):411-417. [PubMed] DOI: 10.1016/s0952-8180(03)00079-5

14. Woldegerima $Y$, Kemal S. Clinical audit on the practice of documentation at preanesthetic evaluation in a specialized university hospital. Int J Surg Open. 2019;16:1-5. DOI: 10.1016/j.ijso.2018.10.006

15. College of Anaesthesiologists Academy of Medicine of Malaysia. Recommendations on pre-anesthetic assessment. (Accessed on 20 April 2020). Available from:

http://www.acadmed.org.my/view_file.cfm?fileid=640

16. The American Society of Anesthesiologists.Statement on Documentation of Anesthesia Care. (Accessed on 20 March 2020). Available from: https://www.asahq.org/ /media/sites/asahq/files/public/ resources/standards-guidelines/guidelines-for-officebased-anesthesia.pdf

17. Australian and New Zealand College of Anesthetists. The Anesthesia Record. Recommendations on the Recording of an Episode of Anesthesia Care. (Accessed on 25 March 2020).Available from: http://www.anzca.edu.au/documents/ps06-2006-theanesthesia-record-recommendations-0.pdf

18. Association of Anesthetists of Great Britain and Ireland. Information Management: Guidance for Anesthetists. (Accessed on 25 March 2020). Available from:

https://www.aagbi.org/sites/default/files/info managem ent08.pdf

19. Merchant R, Bosenberg C, Brown K, Chartrand D, Dain $S$, Dobson J, et al. Guidelines to the practice of anesthesia (revised edition 2010). Can J Anesth. 2010;57:58-87. [PubMed] DOI: 10.1007/s12630-009$\underline{9209-4}$

20. Simmonds M, Petterson J. Anesthetists' records of preoperative assessment. Clin Perform Qual Health Care. 2000;8:22-27. [PubMed]

DOI: 10.1108/14664100010332964

21. Mokgwathi GT, Baloyi BJ, Ogubanjo GA. An audit of preoperative evaluation of general surgery patients at $\mathrm{Dr}$ George Mukhari Hospital. S Afr J Anaesthesiol Anag. 2011;17(2):177-180.

DOI: 10.1080/22201173.2011.10872772

22. Farooq M, Kirke C, Foley K. Documentation of drug allergy on chart in patients presenting for surgery. Ir J Med Sci. 2008;177:243-245. [PubMed] DOl: 10.1007/s11845-008-0166-7

23. Raff M, James MF. An audit of anesthetic record keeping. South Afr J Anaesth Analg. 2013;9:7-9. DOI: 10.1080/22201173.2003.10873005

24. Gebremedhn EG, Nagaratnam V. Audit on anesthetic record completeness at a university teaching hospital operation theater of low-resource setting, 2013. J Anesth Crit Care (Open Access). 2013;8(2):00298. DOI: 10.15406/jaccoa.2017.08.00298 


\section{Appendices}

\section{Appendix A: Predefined parameters used to evaluate the completeness of the studied anesthetic records for the preoperative phase}

\begin{tabular}{|c|c|c|c|}
\hline \multicolumn{4}{|c|}{ PREOPERATIVE } \\
\hline Item & 'complete' & 'incomplete' & ‘no’ \\
\hline \multicolumn{4}{|c|}{ Details regarding operation: } \\
\hline $\begin{array}{l}\text { Date of } \\
\text { preoperative } \\
\text { assessment }\end{array}$ & Date of preoperative assessment provided & $\begin{array}{l}\text { Date of preoperative assessment } \\
\text { provided but illegible }\end{array}$ & Field blank \\
\hline Diagnosis & Diagnosis recorded & $\begin{array}{l}\text { Diagnosis recorded with uncertainty or } \\
\text { illegible }\end{array}$ & Field blank \\
\hline $\begin{array}{l}\text { Surgical } \\
\text { procedure }\end{array}$ & Surgical procedure recorded & $\begin{array}{l}\text { Surgical procedure recorded with } \\
\text { uncertainty or illegible }\end{array}$ & Field blank \\
\hline $\begin{array}{l}\text { Name of } \\
\text { anesthetist }\end{array}$ & Name of anesthetist recorded & $\begin{array}{l}\text { Name of anesthetist recorded but } \\
\text { illegible }\end{array}$ & Field blank \\
\hline $\begin{array}{l}\text { Name of } \\
\text { surgeon }\end{array}$ & Name of surgeon recorded & Name of surgeon recorded but illegible & Field blank \\
\hline $\begin{array}{l}\text { Type of } \\
\text { operation }\end{array}$ & Check mark filled for: elective or emergency & Not applicable & $\begin{array}{l}\text { No check } \\
\text { mark }\end{array}$ \\
\hline $\begin{array}{l}\text { Anesthesia } \\
\text { given in: }\end{array}$ & $\begin{array}{l}\text { Check mark filled for: operating room or maternity } \\
\text { room or } A \& E / \text { polyclinic/ward }\end{array}$ & Not applicable & $\begin{array}{l}\text { No check } \\
\text { mark }\end{array}$ \\
\hline Consent given & Check mark filled for: yes or no or waiting & Not applicable & $\begin{array}{l}\text { No check } \\
\text { mark }\end{array}$ \\
\hline \multicolumn{4}{|c|}{ Details regarding patient: } \\
\hline Patient's name & Patient's name provided & Patient's name provided but illegible & Field blank \\
\hline Patient's RN & Patient's RN provided & Patient's RN provided but illegible & Field blank \\
\hline Patient's age & Patient's age provided & Patient's age provided but illegible & Field blank \\
\hline Patient's gender & Patient's gender provided & Patient's gender provided but illegible & Field blank \\
\hline Patient's weight & Patient's weight recorded & Patient's age recorded but illegible & Field blank \\
\hline $\begin{array}{l}\text { Past medical } \\
\text { history }\end{array}$ & $\begin{array}{l}\text { Past medical history recorded or 'no medical } \\
\text { illness' specified }\end{array}$ & $\begin{array}{l}\text { Past medical history recorded but } \\
\text { illegible }\end{array}$ & Field blank \\
\hline $\begin{array}{l}\text { Previous } \\
\text { surgeries }\end{array}$ & Previous surgeries recorded and dates specified & $\begin{array}{l}\text { Previous surgeries recorded but dates } \\
\text { not specified }\end{array}$ & Field blank \\
\hline $\begin{array}{l}\text { Anesthetic } \\
\text { history }\end{array}$ & $\begin{array}{l}\text { Anesthetic history with any complications or } \\
\text { 'uneventful' recorded }\end{array}$ & $\begin{array}{l}\text { Anesthetic history recorded without } \\
\text { specifying complications }\end{array}$ & Field blank \\
\hline $\begin{array}{l}\text { Current and } \\
\text { previous } \\
\text { medications }\end{array}$ & Medications provided with dosages was specified & $\begin{array}{l}\text { Medications provided but without } \\
\text { specifying dosages }\end{array}$ & Field blank \\
\hline Allergies & Allergies recorded or 'no allergies' specified & $\begin{array}{l}\text { Allergies recorded with uncertainty } \\
\text { (question mark noted) }\end{array}$ & Field blank \\
\hline \multicolumn{4}{|c|}{ Clinical examination: } \\
\hline $\begin{array}{l}\text { General clinical } \\
\text { findings }\end{array}$ & $\begin{array}{l}\text { General clinical findings recorded, and check } \\
\text { mark filled for pallor, cyanosis, edema, jaundice }\end{array}$ & $\begin{array}{l}\text { General clinical findings recorded but } \\
\text { check mark not filled for pallor, } \\
\text { cyanosis, edema, jaundice }\end{array}$ & $\begin{array}{l}\text { Field blank } \\
\text { and no } \\
\text { check mark }\end{array}$ \\
\hline $\begin{array}{l}\text { Airway and } \\
\text { respiratory }\end{array}$ & Teeth, denture, airway and lung findings recorded & $\begin{array}{l}\text { One or two, but not all airway and } \\
\text { respiratory findings recorded }\end{array}$ & $\begin{array}{l}\text { Field blank } \\
\text { or no check } \\
\text { mark }\end{array}$ \\
\hline Cardiovascular & $\begin{array}{l}\text { Blood pressure, heart rate, sound and rhythm, } \\
\text { and peripheral pulse recorded }\end{array}$ & $\begin{array}{l}\text { One or two, but not all cardiovascular } \\
\text { findings recorded }\end{array}$ & $\begin{array}{l}\text { Field blank } \\
\text { or no check } \\
\text { mark }\end{array}$ \\
\hline
\end{tabular}




\begin{tabular}{|c|c|c|c|}
\hline Other system & $\begin{array}{l}\text { Other systems such as neurological or abdominal } \\
\text { findings relevant to patient }\end{array}$ & $\begin{array}{l}\text { Other systems recorded but not really } \\
\text { relevant or illegible }\end{array}$ & Field blank \\
\hline \multicolumn{4}{|c|}{ Investigation results: } \\
\hline Laboratory & $\begin{array}{l}\mathrm{FBC}, \mathrm{RP} \text { and other laboratory results relevant to } \\
\text { diagnosis and proposed surgery recorded }\end{array}$ & $\begin{array}{l}\text { One or two, but not all laboratory } \\
\text { results relevant to diagnosis and } \\
\text { proposed surgery recorded }\end{array}$ & Field blank \\
\hline Other & $\begin{array}{l}\text { ECG, chest X-ray, and other relevant } \\
\text { investigations related to diagnosis and proposed } \\
\text { surgery recorded }\end{array}$ & $\begin{array}{l}\text { One or two, but not all relevant } \\
\text { investigations } \\
\text { Related to diagnosis and proposed } \\
\text { surgery recorded }\end{array}$ & Field blank \\
\hline \multicolumn{4}{|l|}{ Orders: } \\
\hline Special orders & $\begin{array}{l}\text { Anesthetic plans and special orders to be carried } \\
\text { out prior to anesthesia are recorded }\end{array}$ & $\begin{array}{l}\text { Anesthetic plans and specials orders } \\
\text { recorded but illegible }\end{array}$ & Field blank \\
\hline Blood order & Blood order specified & Blood order specified but illegible & Field blank \\
\hline $\begin{array}{l}\text { Premedication } \\
\text { prescribed }\end{array}$ & Premedication prescribed and dosage specified & $\begin{array}{l}\text { Premedication prescribed without } \\
\text { specifying dosages or illegible }\end{array}$ & Field blank \\
\hline
\end{tabular}

\section{Appendix B: Predefined parameters used to evaluate the completeness of the studied anesthetic records for the intraoperative phase}

\begin{tabular}{|c|c|c|c|}
\hline \multicolumn{4}{|c|}{ INTRAOPERATIVE } \\
\hline Item & ‘complete’ & 'incomplete' & ‘no’ \\
\hline $\begin{array}{l}\text { Medications } \\
\text { administered }\end{array}$ & Medications administered and dosage recorded & $\begin{array}{l}\text { Medications administered recorded, } \\
\text { but without specifying dosage }\end{array}$ & Field blank \\
\hline Induction time & Induction time recorded and marked on chart & $\begin{array}{l}\text { Induction time marked, but without } \\
\text { specifying time }\end{array}$ & $\begin{array}{l}\text { No induction } \\
\text { time recorded }\end{array}$ \\
\hline Reversal time & Reversal time recorded and marked on chart & $\begin{array}{l}\text { Reversal time marked, but without } \\
\text { specifying time }\end{array}$ & $\begin{array}{l}\text { No reversal } \\
\text { time recorded }\end{array}$ \\
\hline Regional block & $\begin{array}{l}\text { Types and dosage of regional block given } \\
\text { recorded; or not relevant to operation }\end{array}$ & $\begin{array}{l}\text { Types of regional block recorded, but } \\
\text { without specifying dosage }\end{array}$ & $\begin{array}{l}\text { Field blank or } \\
\text { no check mark }\end{array}$ \\
\hline $\begin{array}{l}\text { Tourniquet } \\
\text { time }\end{array}$ & $\begin{array}{l}\text { Tourniquet time on/off and duration recorded; or } \\
\text { not relevant to operation }\end{array}$ & $\begin{array}{l}\text { Time of tourniquet on recorded, but no } \\
\text { duration specified }\end{array}$ & Field blank \\
\hline $\begin{array}{l}\text { Position of } \\
\text { patient }\end{array}$ & Position of patient recorded & $\begin{array}{l}\text { Position of patient recorded but } \\
\text { illegible }\end{array}$ & Field blank \\
\hline $\begin{array}{l}\text { Pharyngeal } \\
\text { airway } \\
\text { apparatus }\end{array}$ & $\begin{array}{l}\text { Pharyngeal airway apparatus check mark filled } \\
\text { for oral or nasal; or not relevant to operation }\end{array}$ & Not applicable & No check mark \\
\hline Intubation & $\begin{array}{l}\text { Type and size of ETT, and any intubation issues } \\
\text { recorded; or not relevant to operation }\end{array}$ & $\begin{array}{l}\text { One or two, but not all documentation } \\
\text { regarding intubation recorded }\end{array}$ & $\begin{array}{l}\text { Field blank or } \\
\text { no check mark }\end{array}$ \\
\hline $\begin{array}{l}\text { Inhalational } \\
\text { agents }\end{array}$ & $\begin{array}{l}\text { Inhalational agents used throughout operations } \\
\text { recorded; or not relevant to operations }\end{array}$ & $\begin{array}{l}\text { Inhalational agents used throughout } \\
\text { operation recorded, but illegible }\end{array}$ & $\begin{array}{l}\text { Field blank or } \\
\text { no check mark }\end{array}$ \\
\hline Ventilation & $\begin{array}{l}\text { Check mark filled for spontaneous or controlled, } \\
\text { and type of ventilator recorded; or not relevant to } \\
\text { operations }\end{array}$ & $\begin{array}{l}\text { One or two, but not all documentation } \\
\text { regarding ventilation recorded }\end{array}$ & $\begin{array}{l}\text { Field blank or } \\
\text { no check mark }\end{array}$ \\
\hline Vital signs & $\begin{array}{l}\text { Intraoperative blood pressure, heart rate and } \\
\text { saturations recorded every } 10 \text { minutes }\end{array}$ & $\begin{array}{l}\text { One or two, but not all intraoperative } \\
\text { vital signs recorded, but inconsistent }\end{array}$ & $\begin{array}{l}\text { No vital signs } \\
\text { recorded }\end{array}$ \\
\hline Blood loss & Blood loss at the end of operation is recorded & $\begin{array}{l}\text { Blood loss at the end of operation is } \\
\text { recorded but illegible }\end{array}$ & Field blank \\
\hline $\begin{array}{l}\text { Blood } \\
\text { products given }\end{array}$ & $\begin{array}{l}\text { Section for 'blood products' given during } \\
\text { operation recorded correctly }\end{array}$ & $\begin{array}{l}\text { Section for 'blood products' recorded, } \\
\text { but wrongly such as 'IV access', or } \\
\text { illegible }\end{array}$ & Field blank \\
\hline Fluid therapy & Fluid therapy given during operation recorded & $\begin{array}{l}\text { Fluid therapy given during operation } \\
\text { recorded but illegible }\end{array}$ & Field blank \\
\hline
\end{tabular}


Appendix C: Predefined parameters used to evaluate the completeness of the studied anesthetic records for the postoperative phase

\begin{tabular}{|l|l|l|l|}
\hline \multicolumn{1}{|c|}{ Item } & \multicolumn{1}{|c|}{ 'complete' } & \multicolumn{1}{c|}{ 'incomplete' } & \multicolumn{1}{c|}{ 'no' } \\
\hline $\begin{array}{l}\text { Postoperative } \\
\text { orders }\end{array}$ & Postoperative orders recorded & $\begin{array}{l}\text { Postoperative orders recorded but } \\
\text { illegible }\end{array}$ & Field blank \\
\hline $\begin{array}{l}\text { Discharge } \\
\text { time }\end{array}$ & Discharge time recorded & Discharge time recorded but illegible & Field blank \\
\hline $\begin{array}{l}\text { Anesthetist's } \\
\text { name / } \\
\text { signatures }\end{array}$ & Anesthetist's signature and name provided & $\begin{array}{l}\text { Either anesthetist's signature or name } \\
\text { provided but not both }\end{array}$ & Field blank \\
\hline
\end{tabular}

\section{Appendix D: UKMMC's PAR (front and back page)}
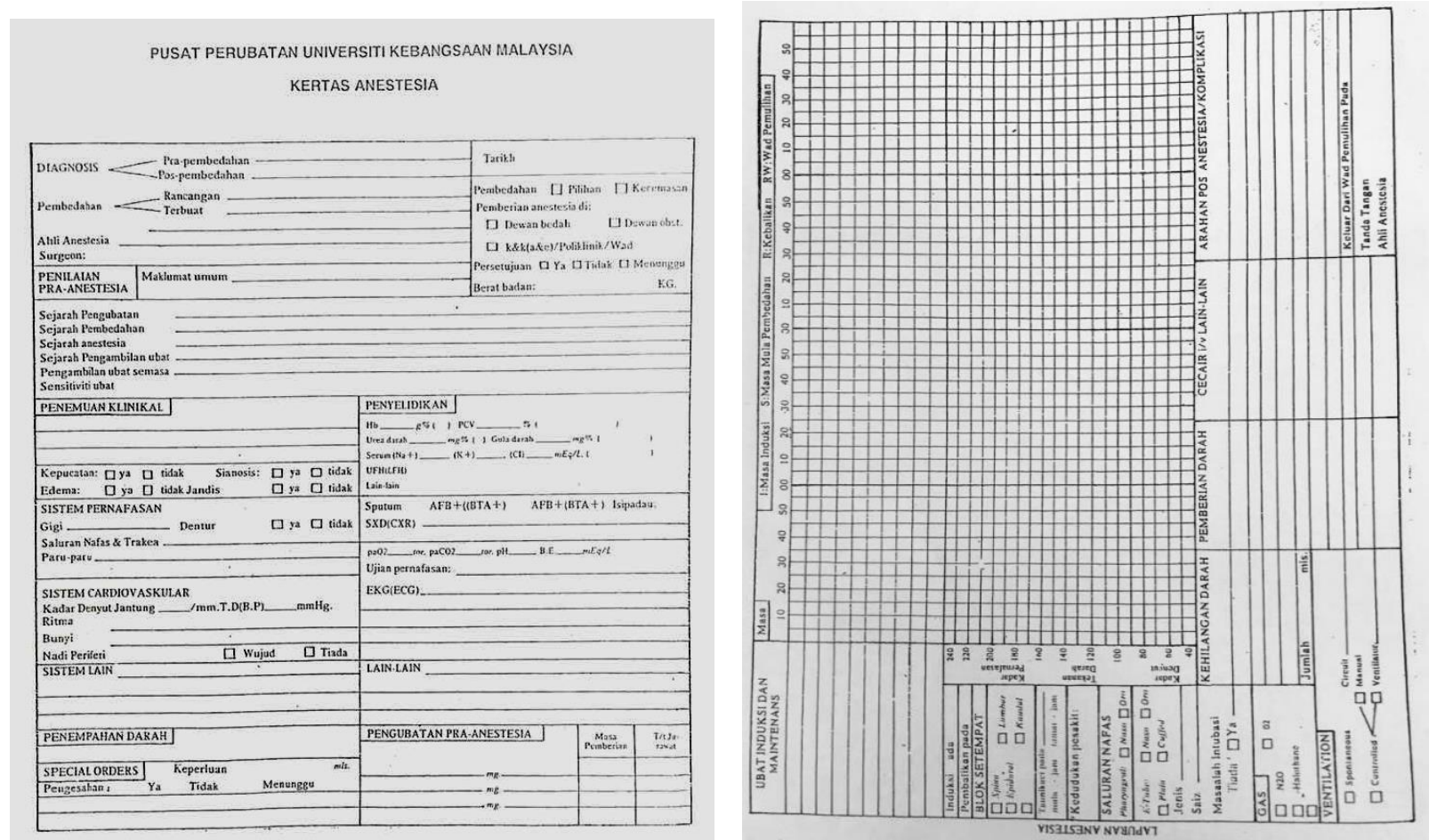